\title{
Chemical Structure and Morphology of Magnetic Ultrafine Particles Synthesized from a Ternary Gaseous Mixture Involving Cobalt Tricarbonyl Nitrosyl
}

\author{
Hiroshi Morita $^{\mathrm{a}, *}$, Koh Hattori ${ }^{\mathrm{b}}$, Nataliya Murafa ${ }^{\mathrm{c}}$, and Jan Šubrt ${ }^{\mathrm{c}}$ \\ ${ }^{a}$ Graduate School of Advanced Integration Science, Chiba University, \\ Yayoi-cho, Inage-ku, Chiba 263-8522, Japan \\ ${ }^{b}$ Graduate School of Science and Technology, Chiba University, \\ Yayoi-cho, Inage-ku, Chiba 263-8522, Japan \\ ${ }^{c}$ Institute of Inorganic Chemistry, Academy of Sciences of the Czech Republic, \\ 25086 Řez near Prague, Czech Republic
}

\begin{abstract}
From a ternary gaseous mixture of cobalt tricarbonyl nitrosyl $\left(\mathrm{Co}(\mathrm{CO})_{3} \mathrm{NO}\right)$, iron pentacarbonyl $\left(\mathrm{Fe}(\mathrm{CO})_{5}\right)$, and 2-propenyltrimethylsilane (allyltrimethylsilane) (ATMeSi), magnetic black fibrous material composed of amorphous ultrafine particles were produced under irradiation with intense Nd:YAG laser light at $355 \mathrm{~nm}$. Chemical structures were studied from FT-IR and Raman spectra. It was shown that $\mathrm{Co}(\mathrm{CO})_{3} \mathrm{NO}$ and $\mathrm{Fe}(\mathrm{CO})_{5}$ molecules evolved terminal $\mathrm{C} \equiv \mathrm{O}$ groups, and $\mathrm{Co}$ and $\mathrm{Fe}$ atoms were connected via bridging $\mathrm{C}=\mathrm{O}$ groups. $\mathrm{ATMeSi}$ also coordinated to $\mathrm{Co}$ atoms via $\mathrm{C}=\mathrm{C}$ double bond of allyl group. The chemical compositions and the morphology of the magnetic particles were analyzed by scanning electron microscopy/energy dispersive spectroscopy (SEM-EDS) and HRTEM images. Small amorphous particles with sizes of less than $50 \mathrm{~nm}$ joined together to form fibers, and crystalline spheres similar to the structure of $\mathrm{Co}_{0.7} \mathrm{Fe}_{0.3}$ were involved in some particles. Magnetization of the ultrafine particles was measured with a SQUID magnetometer. Magnetic susceptibility, $\chi$, of the ultrafine particles was evaluated to be $\sim 2 \times 10^{-2} \mathrm{emu} / \mathrm{g}$, and temperature dependence of $\chi$ supported the ferromagnetic behaviors of the particles. Under a magnetic field of 1-5 $\mathrm{T}$, super-paramagnetic ultrafine particles were also produced in addition to ferromagnetic particles. Existence of several kinds of crystalline spheres was responsible to magnetic properties of the ultrafine particles.
\end{abstract}

Keywords: Gas phase photochemical reaction, Magnetic ultrafine particle, cobalt tricarbonyl nitrosyl, iron pentacarbonyl, 2-propenyltrimethylsilane

\section{Introduction}

Metal containing ultrafine particles are suitable for fabricating nano-patterns in nano-lithography and can be utilized as building blocks of nano-devices [1,2]. These particles were synthesized from organometal compounds such as iron pentacarbonyl $\left(\mathrm{Fe}(\mathrm{CO})_{5}\right)$ and cobalt tricarbonyl nitrosyl $\left(\mathrm{Co}(\mathrm{CO})_{3} \mathrm{NO}\right)[3,4]$ using the photochemical method where photochemical reactions of reactive molecules initiated nucleation reactions during aerosol particle formation $[5,6]$. 2-Propenyl-trimethylsilane (allyltrimethylsilane) (ATMeSi) can ligate to metal atoms via $\pi$-coordination of allyl group, and can incorporate into the nucleation reaction during aerosol particle formation $[7,8]$.

From a ternary gaseous mixture of $\mathrm{Co}(\mathrm{CO})_{3} \mathrm{NO}$, $\mathrm{Fe}(\mathrm{CO})_{5}$, and ATMeSi, spherical aerosol particles with a mean diameter of $0.36 \mu \mathrm{m}$ were produced under UV light irradiation [9]. Addition of ATMeSi accelerated the chemical reactions of $\mathrm{Co}(\mathrm{CO})_{3} \mathrm{NO}$ to produce aerosol particles efficiently, and decelerated those of $\mathrm{Fe}(\mathrm{CO})_{5}$ to inhibit the formation of crystalline deposits which were mainly composed of $\mathrm{Fe}_{2}(\mathrm{CO})_{9}$ structure involving $\mathrm{Fe}-\mathrm{C}(=\mathrm{O})-\mathrm{Co}$ bond. ATMeSi molecules played an 
essential role to form spherical particles being rich in Co species.

Magnetic ultrafine particles have been produced successfully under irradiation with intense Nd:YAG laser light [6]. From a gaseous mixture of $\mathrm{Fe}(\mathrm{CO})_{5}$ and trimethylsilyl azide (TMSAz), magnetic ultrafine particles which were composed of ferromagnetic and super-paramagnetic particles were prepared [10, 11]. From a ternary gaseous mixture of $\mathrm{Co}(\mathrm{CO})_{3} \mathrm{NO}$, tetraethylgermane (TEG), and ATMeSi, ferromagnetic ultrafine particles were also produced under irradiation with intense $\mathrm{Nd}$ :YAG laser light [12]. From the analysis of HRTEM images, ultrafine particles were composed of several kinds of particles which involved both the polycrystalline micro-domain and amorphous micro-domain. Crystalline micro-domain was mainly composed of $\mathrm{Co}$ atoms, and responsible for ferromagnetic properties of the particles.

In the present study, magnetic ultrafine particles were prepared from a ternary gaseous mixture of $\mathrm{Co}(\mathrm{CO})_{3} \mathrm{NO}, \mathrm{Fe}(\mathrm{CO})_{5}$, and $\mathrm{ATMeSi}$ under intense laser light irradiation with an Nd:YAG laser. The chemical structure of the magnetic particles was studied from FT-IR and Raman spectra, and the chemical compositions and the morphology of the magnetic particles were analyzed by scanning electron microscopy/energy dispersive spectro-scopy (SEM-EDS) and HRTEM images. Magnetic properties were discussed briefly by measuring the magnetic susceptibility of the ultrafine particles.

\section{Experimental}

$\mathrm{Co}(\mathrm{CO})_{3} \mathrm{NO}$ (Gelest, 95\%), $\mathrm{Fe}(\mathrm{CO})_{5}$ (Kanto, 95\%), and ATMeSi (Tokyo Kasei, G. R. grade) were degassed by freeze-pump-thaw cycles in the dark and purified by vacuum distillation immediately before use. To prepare a gaseous mixture of $\mathrm{Co}(\mathrm{CO})_{3} \mathrm{NO}, \mathrm{Fe}(\mathrm{CO})_{5}$, and $\mathrm{ATMeSi}$, each vapor was introduced successively into a cross-shaped Pyrex cell (volume $168 \mathrm{~cm}^{3}$ ) having a long (length $160 \mathrm{~mm}$, inner diameter $35 \mathrm{~mm}$ ) and short (length $80 \mathrm{~mm}$, inner diameter $20 \mathrm{~mm}$ ) arms or into a small cylindrical Pyrex cell (length 160 $\mathrm{mm}$, inner diameter $20 \mathrm{~mm}$, volume $50 \mathrm{~cm}^{3}$ ) equipped with a couple of quartz windows through a vacuum line equipped with a capacitance manometer (Edwards Barocel Type 600). The background pressure of the irradiation cell was less than $1 \times 10^{-4}$ Torr $(1$ Torr $=133.3 \mathrm{~Pa})$. The partial pressures of $\mathrm{Co}(\mathrm{CO})_{3} \mathrm{NO}, \mathrm{Fe}(\mathrm{CO})_{5}$, and ATMeSi in the irradiation cell were determined from the diagnostic band intensities of FT-IR spectra at $2108 \mathrm{~cm}^{-1}$ for $\mathrm{Co}(\mathrm{CO})_{3} \mathrm{NO}, 645 \mathrm{~cm}^{-1}$ for $\mathrm{Fe}(\mathrm{CO})_{5}$, and $854 \mathrm{~cm}^{-1}$ for ATMeSi.

The gaseous samples were irradiated with the third harmonics $(355 \mathrm{~nm})$ of pulsed Nd:YAG laser light (Continuum Surelite I-10, pulse width $6 \mathrm{~ns}$, repetition rate $10 \mathrm{~Hz}$ ) (energy, $35 \sim 38 \mathrm{~mJ} /$ pulse). Absorbance of 1 Torr of $\mathrm{Co}(\mathrm{CO})_{3} \mathrm{NO}$ and of $\mathrm{Fe}(\mathrm{CO})_{5}$ is 0.19 and 0.07 , respectively, at $355 \mathrm{~nm}$ in $10 \mathrm{~cm}$ light path length. ATMeSi does not absorb any light at longer wavelengths than 220 $\mathrm{nm}$ in case of one-photon excitation. Sedimentary particles were deposited on a glass plate and/or $\mathrm{Cu}$ substrate placed at the bottom of the irradiation cell.

Scanning electron microscope (SEM) images were recorded with a JEOL JSM 6060 scanning electron microscope. SEM-EDS analyses were performed using a Philips XL30 CP EDAX scanning electron microscope, and HRTEM images were recorded with a JEOL JEM 3010 high resolution transmission electron microscope with $\mathrm{LaB}_{6}$ cathode operating at accelerating voltage of $300 \mathrm{kV}$. FT-IR spectra of the gaseous mixtures and of the deposited particles embedded in $\mathrm{KBr}$ pellets were measured with a Nicolet NEXUS 470 FT-IR spectrometer. Magnetization of the deposited particles was measured with a SQUID magnetometer (Quantum Design MPMS-5S). Magnetic field was applied by a helium-free superconducting magnet (Toshiba TM-5SP).

\section{Results and discussion}

3.1. Magnetic particle formation under light irradiation with an Nd:YAG laser

Under irradiation with intense Nd:YAG laser light at $355 \mathrm{~nm}$ for $3 \mathrm{~min}$, a ternary gaseous mixture of $\mathrm{Co}(\mathrm{CO})_{3} \mathrm{NO}$ (3.5 Torr), $\mathrm{Fe}(\mathrm{CO})_{5}(1.4$ Torr), and ATMeSi (8.0 Torr) produced coagulated black fibrous material composed of ultrafine particles with sizes of less than $50 \mathrm{~nm}$ (Fig. 1A). Black particles were magnetic as discussed later. FT-IR spectrum of the deposited particles is shown in Fig. 2A. Under Nd:YAG laser light irradiation at $355 \mathrm{~nm}$ through a concave lens with a focal length of $40 \mathrm{~mm}$, a ternary gaseous mixture of $\mathrm{Co}(\mathrm{CO})_{3} \mathrm{NO}$ (3.5 Torr), $\mathrm{Fe}(\mathrm{CO})_{5}$ (1.4 Torr), and ATMeSi (8.0 Torr) produced spherical particles with a mean diameter of $0.60 \mu \mathrm{m}$ (Fig. 1B). FT-IR spectrum of the deposited particles is shown in Fig. 2B. Morphological change of the deposits clearly showed that multiphoton processes due to intense 
laser light took place in the nucleation reactions during magnetic particle formation.

Compared to the spectrum of the deposited particles shown in Fig. 2B, black ultrafine particles
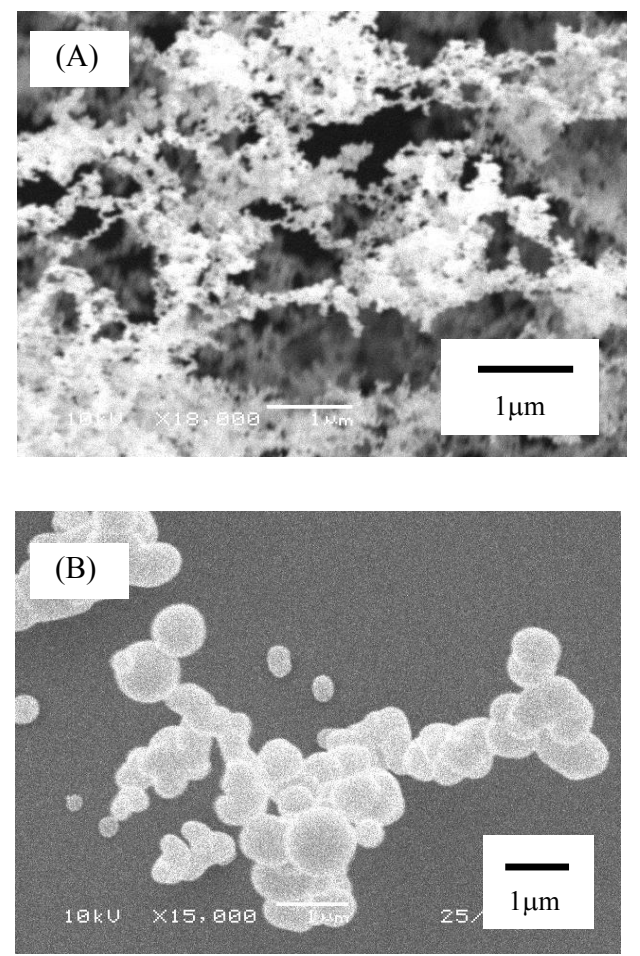

Fig. 1. SEM images of sedimentary ultrafine particles produced from a ternary gaseous mixture of $\mathrm{Co}(\mathrm{CO})_{3} \mathrm{NO}$ (3.5 Torr), $\mathrm{Fe}(\mathrm{CO})_{5}$ (1.4 Torr), and ATMeSi (8.0 Torr) under irradiation with the third harmonics of Nd:YAG laser light at $355 \mathrm{~nm}$ (A) directly and (B) through a concave lens with a focal length of $40 \mathrm{~mm}$ for $3 \mathrm{~min}$. Original magnification of SEM, (A) $18,000 \times$ (B) $15,000 \times$.

showed strong bands at 1867 and $1799 \mathrm{~cm}^{-1}$ assigned to a bridging $>\mathrm{C}=\mathrm{O}$ group, whereas $\mathrm{C}-\mathrm{O}$ stretching bands at $2026 \mathrm{~cm}^{-1}$ assigned to the terminal $\mathrm{C} \equiv \mathrm{O}$ group of $\mathrm{Co}(\mathrm{CO})_{3} \mathrm{NO}$ almost disappeared. Moreover, three bands characteristic of trimethylsilyl group at 1254,841 , and $756 \mathrm{~cm}^{-1}$ [13] became stronger, and a new broad band appeared at $1030 \mathrm{~cm}^{-1}$. The $1030 \mathrm{~cm}^{-1}$ band was assignable to $v(\mathrm{Si}-\mathrm{O})$ of siloxane structure [14]. From FT-IR spectra, it was strongly suggested that terminal $\mathrm{C} \equiv \mathrm{O}$ groups of $\mathrm{Co}(\mathrm{CO})_{3} \mathrm{NO}$ and $\mathrm{Fe}(\mathrm{CO})_{5}$ were evolved under intense laser light irradiation, and $\mathrm{Co}$ and $\mathrm{Fe}$ atoms were connected through bridging $\mathrm{C}=\mathrm{O}$ groups. During ultrafine particle formation, ATMeSi coordinated to Co atoms via $\mathrm{C}=\mathrm{C}$ double bond of allyl group $[9,15]$.

Raman spectrum of the black ultrafine particles
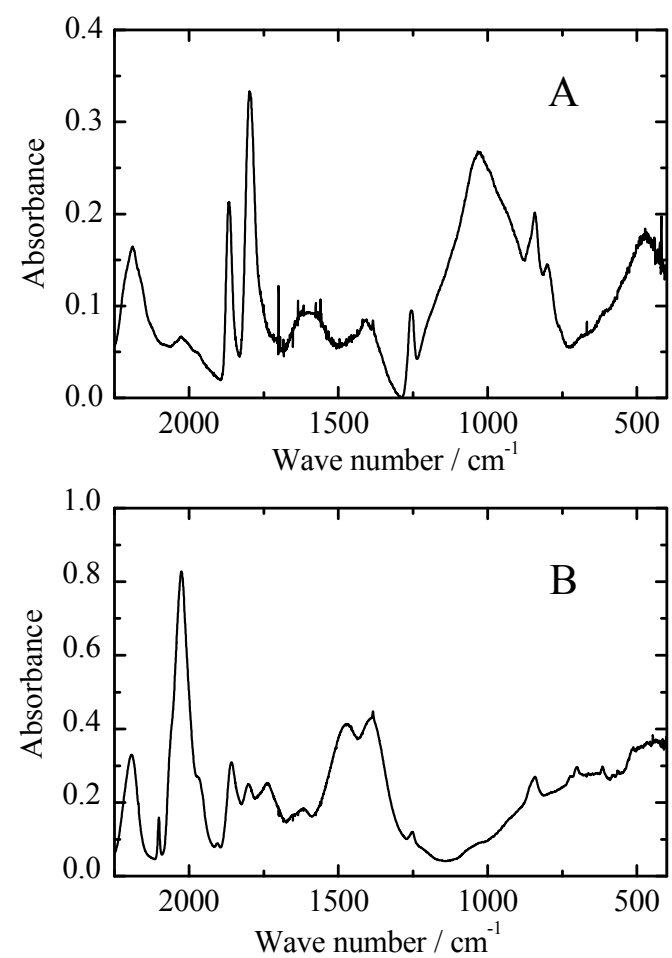

Fig. 2. FT-IR spectra of sedimentary ultrafine particles produced from a ternary gaseous mixture of $\mathrm{Co}(\mathrm{CO})_{3} \mathrm{NO}$ (3.5 Torr), $\mathrm{Fe}(\mathrm{CO})_{5}$ (1.4 Torr), and ATMeSi (8.0 Torr) under irradiation with the third harmonics of Nd:YAG laser light at $355 \mathrm{~nm}$ (A) directly and (B) through a concave lens with a focal length of $40 \mathrm{~mm}$ for $3 \mathrm{~min}$.

produced from a ternary gaseous mixture of $\mathrm{Co}(\mathrm{CO})_{3} \mathrm{NO}$ (3.5 Torr), $\mathrm{Fe}(\mathrm{CO})_{5}$ (1.4 Torr), and ATMeSi (8.0 Torr) is shown in Fig. 3A. Due to small amount of the ultrafine particles deposited on a glass plate, background signal coming from the light scattering on a glass plate was relatively large (Fig. 3B). However, reproducible peaks were observed at 379 and $161 \mathrm{~cm}^{-1}$ assignable to $\delta(\mathrm{Co}-\mathrm{CO})$ and $v(\mathrm{Co}-\mathrm{Co})$, respectively, suggesting that $\mathrm{Co}-(\mathrm{CO})-\mathrm{Co}$ and $\mathrm{Co}-(\mathrm{CO})-\mathrm{Fe}$ structures which were observed such as in $\mathrm{Co}_{2}(\mathrm{CO})_{8}$ species were involved in the ultrafine particles.

SEM-EDS analysis showed that atomic ratio of $\mathrm{Co}$ to $\mathrm{Fe}, \mathrm{Si}, \mathrm{C}$, and $\mathrm{O}$ atoms of the ultrafine particles deposited from the ternary gaseous mixture of $\mathrm{Co}(\mathrm{CO})_{3} \mathrm{NO}$ (3.5 Torr), $\mathrm{Fe}(\mathrm{CO})_{5}(1.4$ Torr), and ATMeSi (8.0 Torr) was $1: 0.06: 0.23$ : $1.78: 1.18$. Compared to the atomic ratio of Co to $\mathrm{Fe}$ and $\mathrm{Si}$ atoms $(1: 0.14: 0.04)$ observed with the particles produced under irradiation with weaker YAG laser light through a concave lens with a focal length of $120 \mathrm{~mm}$ [9], the magnetic ultrafine particles involved much more Co atoms, 


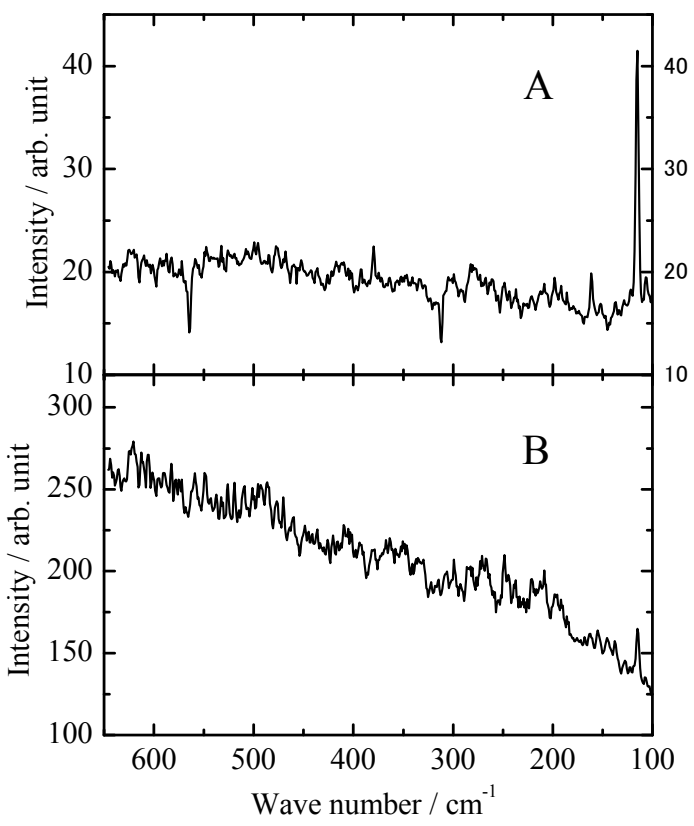

Fig. 3. (A) Raman spectrum of magnetic ultrafine particles produced from a ternary gaseous mixture of $\mathrm{Co}(\mathrm{CO})_{3} \mathrm{NO}$ (3.5 Torr), $\mathrm{Fe}(\mathrm{CO})_{5}$ (1.4 Torr), and ATMeSi (8.0 Torr) under irradiation with the third harmonics of Nd:YAG laser light at $355 \mathrm{~nm}$ and (B) light scattering on a glass plate.

3.2. Morphological characteristics of magnetic ultrafine particles

To investigate the morphological characteristics of the magnetic ultrafine particles in more detail, HRTEM measurements were carried out for the ultrafine particles deposited from a ternary gaseous mixture of $\mathrm{Co}(\mathrm{CO})_{3} \mathrm{NO}$ (3.5 Torr), $\mathrm{Fe}(\mathrm{CO})_{5}(1.4$ Torr), and ATMeSi (8.0 Torr). As shown in Fig. 4, small amorphous particles with sizes less than 50 $\mathrm{nm}$ joined together to form fibers, and crystalline spheres were involved in some particles. Crystalline spheres are shown in Fig. 5. The distance between crystal planes was observed to be $0.193,0.198$, or $0.204 \mathrm{~nm}$ at several crystalline spheres, showing that atomic compositions and crystal structures were slightly different from each other.

Electron diffraction pattern of the crystalline phase was recorded, and fitted with data from XRD databases. The best fit was achieved with one of the $\mathrm{Fe}-\mathrm{Co}$ alloys, i.e., $\mathrm{Co}_{0.7} \mathrm{Fe}_{0.3}$ (Fig. 6) although the fit was not fully perfect. The results showed that the crystalline phase was mainly composed of Co atoms, and had not yet been included in the database.

HRTEM-EDS measurements were also carried (a)

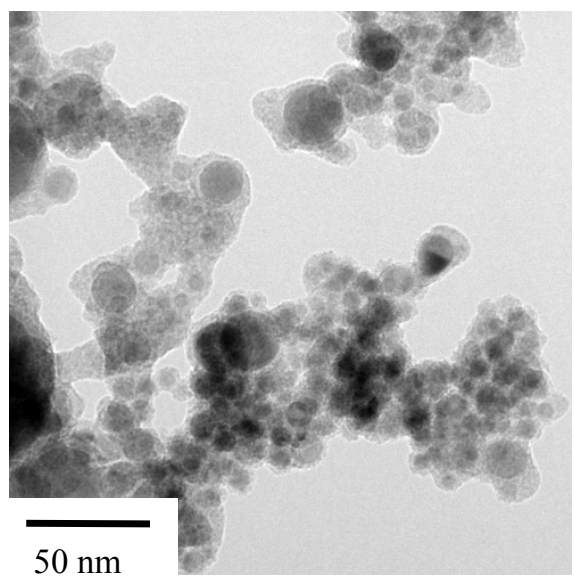

(b)

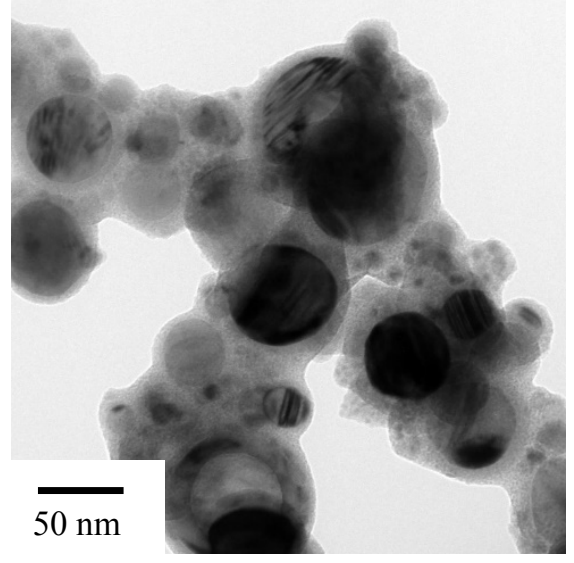

Fig. 4. HRTEM images of magnetic ultrafine particles produced from a ternary gaseous mixture of $\mathrm{Co}(\mathrm{CO})_{3} \mathrm{NO}$ (3.5 Torr), $\mathrm{Fe}(\mathrm{CO})_{5}$ (1.4 Torr), and ATMeSi (8.0 Torr) measured at two spots, (a) and (b).

out at several crystalline spheres. The average value of the atomic ratio of $\mathrm{Co}$ to $\mathrm{Fe}, \mathrm{Si}, \mathrm{C}$, and $\mathrm{O}$ atoms was $1: 0.15: 0.21: 0.13: 0.16$. HRTEM-EDS analysis was free from the contribution of surface contamination of $\mathrm{Cu}$ substrate frequently observed in SEM-EDS analysis. Hence, the values of the $\mathrm{C}$ and $\mathrm{O}$ atoms were reasonable. The results confirmed that terminal $\mathrm{C} \equiv \mathrm{O}$ groups of $\mathrm{Co}(\mathrm{CO})_{3} \mathrm{NO}$ and $\mathrm{Fe}(\mathrm{CO})_{5}$ were evolved almost completely under intense laser light irradiation and bridging $\mathrm{C}=\mathrm{O}$ groups were involved to connect $\mathrm{Co}$ and/or $\mathrm{Fe}$ atoms.

\subsection{Magnetic properties of magnetic ultrafine particles}

In order to investigate the magnetic properties of the deposited particles, magnetic ultrafine particles were produced from a gaseous mixture of $\mathrm{Co}(\mathrm{CO})_{3} \mathrm{NO}$ (3.9 Torr), $\mathrm{Fe}(\mathrm{CO})_{5}$ (1.2 Torr), and ATMeSi (6.8 Torr) under irradiation with YAG 
(a)

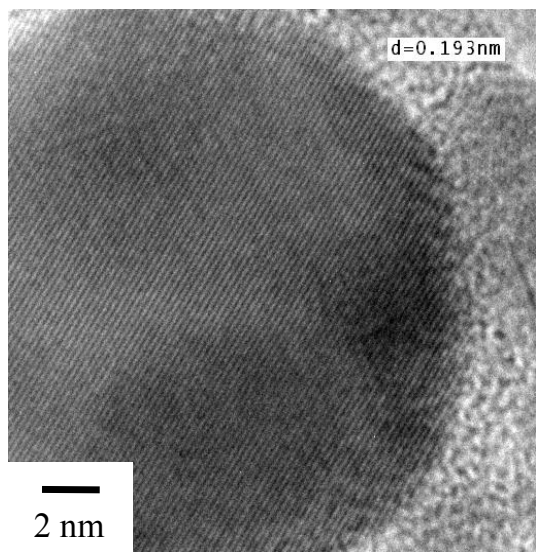

(b)

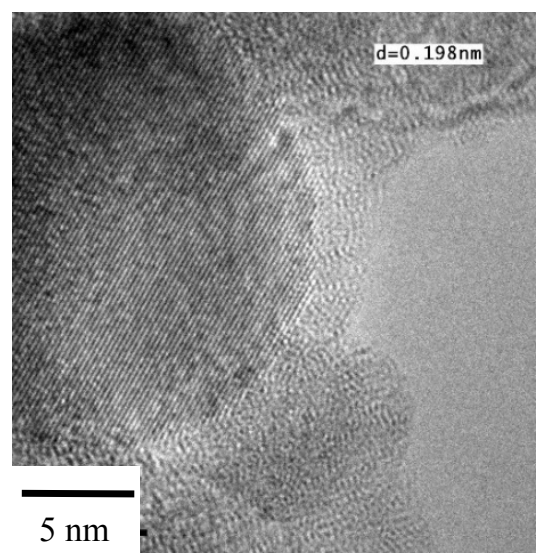

(c)

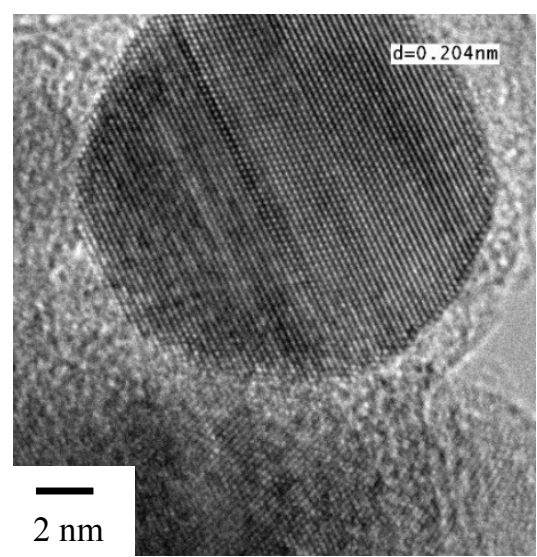

Fig. 5. HRTEM images of crystalline spheres produced from a ternary gaseous mixture of $\mathrm{Co}(\mathrm{CO})_{3} \mathrm{NO}$ (3.5 Torr), $\mathrm{Fe}(\mathrm{CO})_{5}$ (1.4 Torr), and ATMeSi (8.0 Torr) measured at three spots, (a), (b), and (c). Distance between crystal planes is (a) 0.193 , (b) 0.198 , and (c) $0.204 \mathrm{~nm}$.

laser light at $355 \mathrm{~nm}$ for $3 \mathrm{~min}$, and magnetization of the deposited particles was measured with a SQUID magnetometer. The results of the particles produced with the application of a magnetic field of $1.5 \mathrm{~T}$ and measured by SQUID under a magnetic field of $1.5 \mathrm{~T}$ are shown in Fig. 7.
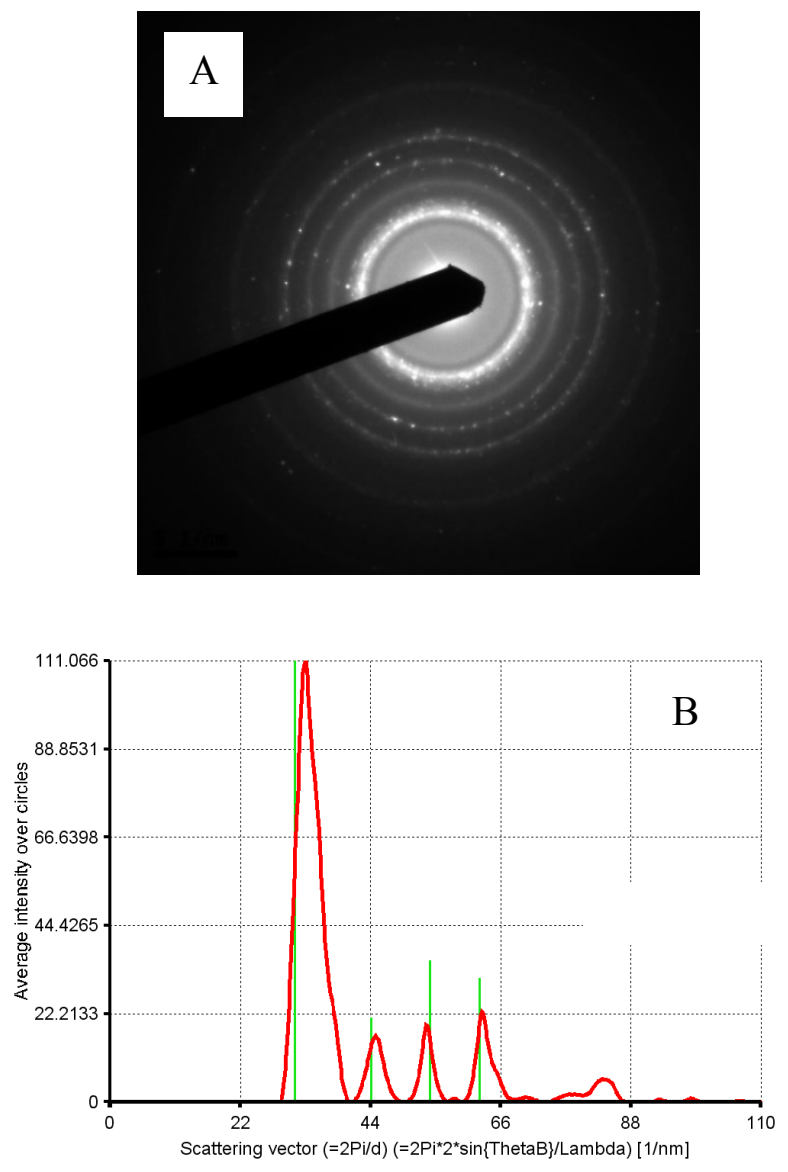

Fig. 6. (A) Electron diffraction pattern of a crystalline sphere (c) in Fig. 5, and (B) simulated curve fitted with $\mathrm{Co}_{0.7} \mathrm{Fe}_{0.3}$ from XRD database.

Magnetic susceptibility, $\chi$, of the ultrafine particles was $\sim 2 \times 10^{-6} \mathrm{emu}$ for the measured sample of $\sim 3$ mg. In the present experiment, the ultrafine particles of $\sim 5 \mathrm{mg}$ were deposited on a piece of Scotch tape of $18 \times 146 \mathrm{~mm}$ and then, the Scotch tape was cut into $18 \times 76 \mathrm{~mm}(\sim 90 \mathrm{mg})$ after the deposition of ultrafine particles to prepare a sample for SQUID measurement. Therefore, we could not determine precisely the amount of particles used for SQUID measurement. As discussed in previous papers [11, 12], the magnetization of the magnetic particles synthesized under irradiation with intense $\mathrm{Nd}$ :YAG laser light saturated at low magnetic field around 500 Oe. Hence, $\chi$ value measured under a magnetic field of $1.5 \mathrm{~T}$ was extrapolated to the value at 500 Oe to be $\sim 6 \times 10^{-5} \mathrm{emu}$ for the amount of $\sim 3 \mathrm{mg}$. Thus, $\chi$ value was only roughly evaluated to be $\sim 2 \times 10^{-2} \mathrm{emu} / \mathrm{g}$ or larger, suggesting that the deposited ultrafine particles were ferromagnetic as discussed in a previous paper [11]. As shown in Fig. 7, $\chi$ value gradually 


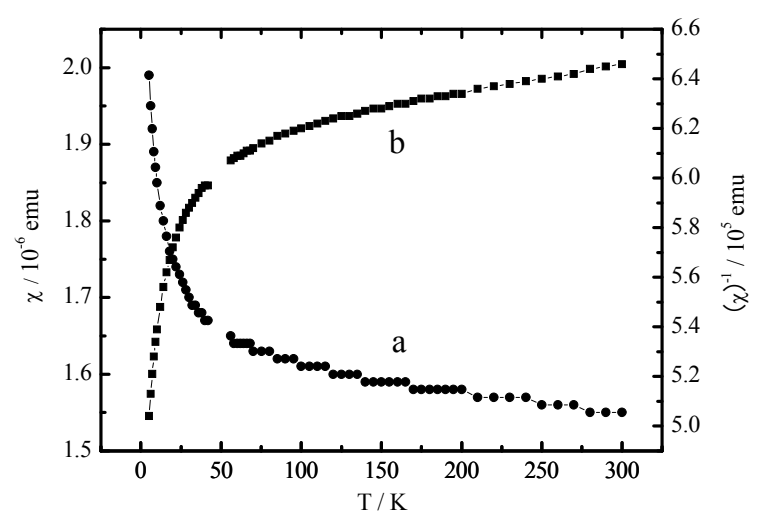

Fig. 7. Magnetic susceptibility $(a ; \chi$ and $b ; 1 / \chi$ ) of deposited magnetic particles produced from a gaseous mixture of $\mathrm{Co}(\mathrm{CO})_{3} \mathrm{NO}$ (3.9 Torr), $\mathrm{Fe}(\mathrm{CO})_{5}$ (1.2 Torr), and ATMeSi (6.8 Torr) under irradiation with YAG laser light at 355 $\mathrm{nm}$ for $3 \mathrm{~min}$ with the application of a magnetic field of 1.5 T. SQUID measurement was performed under a magnetic field of $1.5 \mathrm{~T}$.

increased with decreasing temperature as was usually observed for ferromagnetic particles. In the low temperature region below $30 \mathrm{~K}$, temperature-sensitive component appeared. This can be attributed to the existence of super-paramagnetic species in addition to the ferromagnetic species as in the case of the magnetic particles produced from a gaseous mixture of $\mathrm{Fe}(\mathrm{CO})_{5}$ and TMSAz [11], showing that the magnetic ultrafine particles were composed of two kinds of magnetic particles. Crystalline spheres having slightly different distances of crystal planes may be responsible for the ferromagnetic and super-paramagnetic properties of the magnetic particles.

\section{Conclusions}

From a ternary gaseous mixture of $\mathrm{Co}(\mathrm{CO})_{3} \mathrm{NO}$, $\mathrm{Fe}(\mathrm{CO})_{5}$, and ATMeSi, magnetic amorphous ultrafine particles were produced under irradiation with intense Nd:YAG laser light at $355 \mathrm{~nm}$. From FT-IR and Raman spectra, $\mathrm{Co}$ and $\mathrm{Fe}$ atoms were connected via bridging $\mathrm{C}=\mathrm{O}$ groups, and $\mathrm{ATMeSi}$ coordinated to $\mathrm{Co}$ atoms via $\mathrm{C}=\mathrm{C}$ double bond of allyl group. From SEM-EDS and HRTEM analyses, it was shown that small amorphous particles with sizes of less than $50 \mathrm{~nm}$ joined together to form fibers, and crystalline spheres similar to the structure of $\mathrm{Co}_{0.7} \mathrm{Fe}_{0.3}$ were involved in some particles.

Magnetic susceptibility, $\chi$, of the ultrafine particles measured with a SQUID magnetometer was evaluated to be $\sim 2 \times 10^{-2} \mathrm{emu} / \mathrm{g}$, and temperature dependence of $\chi$ supported the ferro-magnetic behaviors of the particles. Under a magnetic field of 1-5 $\mathrm{T}$, super-paramagnetic ultrafine particles were also produced in addition to ferromagnetic particles. Deposition of several kinds of crystalline spheres was responsible to magnetic properties of the ultrafine particles.

\section{Acknowledgement}

The authors thank to Professor Katsuya Inoue, Hiroshima University for measuring magnetic susceptibility of the deposited particles. The authors also thank Drs. Yoshiaki Hamada and Nakako Tokita of the Open University of Japan for measuring Raman spectrum of the deposits.

\section{References}

1. H. Morita, J. Photopolym. Sci. Technol. 12 (1999) 95.

2. H. Morita, J. Photopolym. Sci. Technol. 21 (2008) 767.

3. H. Morita, Y. Takeyasu, H. Okamura, and H. Ishikawa, Sci. Technol. Adv. Mater. 7 (2006) 389.

4. K. Abe, and H. Morita, J. Photopolym. Sci. Technol. 19 (2006) 135.

5. H. Morita, "Photochemical synthesis of aerosol particles", in "Aerosols: Chemistry, Environmental Impact and Health Effects", D. H. Peretz, Eds., Nova Science, New York (2009) pp. 1-31.

6. H. Morita, "Photochemical synthesis and magnetic field effect on ultrafine particles involving organosilicon and organometal compounds", in "Advances in Nanotechnology. Vol. 8", Z. Bartul and J. Trenor, Eds., Nova Science, New York (2011) pp. 255-289.

7. H. Morita and H. Ishikura, J. Photopolym. Sci. Technol. 18 (2005) 193.

8. H. Morita, H. Sakano, and C. Yamano, J. Photopolym. Sci. Technol. 20 (2007) 117.

9. H. Morita, K. Hattori, and J. Šubrt, J.Photochem. Photobiol. A 218 (2011) 111.

10. H. Morita, Y. Okano, J. Šubrt, Aerosol Sci. Technol. 47 (2013) 1188.

11. H. Morita, Y. Okano, C. Udagawa, S. Morimoto, Y. Tanimoto, Y. Fujiwara, and K. Inoue, J. Photopolym. Sci. Technol. 26 (2013) 459.

12. H. Morita, S. Sakano, N. Murafa, and J. Šubrt, J. Photopolym. Sci. Technol. 27 (2014) 477.

13. J. R. Durig, J. F. Sullivan, A. W. Cox, Jr., and B. J. Streusand, Spectrochim. Acta 34A (1978) 719.

14. M. Urbanova, H. Morita, V. Drinek, Z. Bastl, J. Šubrt, and J. Pola, J. Anal. Appl. Pyrol. 44 (1998) 219.

15. H. Morita, K. Abe, and M. Takahashi, J. Photochem. Photobiol. A 210 (2010) 108. 